\title{
Angelica polysaccharide attenuates LPS- induced inflammation response of primary dairy cow claw dermal cells via NF-KB and MAPK signaling pathways
}

\author{
Mengyue Tian ${ }^{1}, \mathrm{Ke} \mathrm{Li}^{1}$, Ruonan Liu', Jinliang Dư ${ }^{1,2}$, Dongmin Zou ${ }^{3}$ and Yuzhong Ma ${ }^{1 *}$ (D)
}

\begin{abstract}
Background: Laminitis, an inflammation of the claw laminae, is one of the major causes of bovine lameness, which can lead to enormous economic losses and animal welfare problems in dairy farms. Angelica polysaccharide (AP) is proved to possess anti-inflammatory properties. But the role of AP on inflammatory response of the claw dermal cells has not been reported. The aim of this study was to investigate the anti-inflammatory effects of AP on lipopolysaccharide (LPS)-induced primary claw dermal cells of dairy cow and clarify the potential mechanisms. In the current research, the primary claw dermal cells were exposed to gradient concentrations of $\operatorname{AP}(10,50,100 \mu \mathrm{g} /$ $\mathrm{mL}$ ) in the presence of $10 \mu \mathrm{g} / \mathrm{mL}$ LPS. The levels of cytokines and nitric oxide (NO) were detected with ELISA and Griess colorimetric method. The mRNA expressions of TLR4, MyD88 and chemokines were measured with qPCR. The activation of NF-KB and MAPK signaling pathways was detected with western blotting.

Results: The results indicated that AP reduced the production of inflammatory mediators (TNF- $a, I L-1 \beta, I L-6$ and NO), downregulated the mRNA expression of TLR4, MyD88 and some pro-inflammatory chemokines (CCL2, CCL20, CXCL2, CXCL8, CXCL10), and suppressed the NF-KB and MAPK signaling pathways evidenced by inhibition of the phosphorylation of IKBa, p65 and ERK, JNK, p38.

Conclusions: Our results demonstrated that AP may exert its anti-inflammatory effects on claw dermal cells of dairy cow by regulating the NF-KB and MAPK signaling pathways.
\end{abstract}

Keywords: Dairy cow, Claw dermal cell, LPS, Angelica polysaccharide, NF-kB, MAPK

\section{Background}

Lameness is one of the most important and intractable diseases in dairy farms worldwide, which can lead to economic losses and animal welfare problems $[1,2]$. Laminitis, a crucial reason for lameness, is defined as diffuse, aseptic, serous inflammation of the corium [3]. It has been estimated that the prevalence of subclinical

\footnotetext{
* Correspondence: dkma@hebau.edu.cn

${ }^{1}$ College of Veterinary Medicine, Hebei Agricultural University, 2596 Lekai South Street, Hebei 071001 Baoding, China

Full list of author information is available at the end of the article
}

laminitis in large scale dairy farms was $42.0 \%$ in Thailand [4]. Laminitis can lead to other claw diseases, such as sole hemorrhage, sole ulcer, and white line disease, and is also responsible for milk yield reduction, reproduction disorders and weight loss $[5,6]$.

The pathogenesis of laminitis has not been fully elucidated. It is currently believed that nutrition disorder is one of the main causes [7]. The disproportion between a high share of rapidly-fermented carbohydrates and low physical effective NDF may cause impaired ruminal health through variation in the VFA concentrations and

(c) The Author(s). 2021 Open Access This article is licensed under a Creative Commons Attribution 4.0 International License, which permits use, sharing, adaptation, distribution and reproduction in any medium or format, as long as you give appropriate credit to the original author(s) and the source, provide a link to the Creative Commons licence, and indicate if changes were made. The images or other third party material in this article are included in the article's Creative Commons licence, unless indicated otherwise in a credit line to the material. If material is not included in the article's Creative Commons licence and your intended use is not permitted by statutory regulation or exceeds the permitted use, you will need to obtain permission directly from the copyright holder. To view a copy of this licence, visit http://creativecommons.org/licenses/by/4.0/ The Creative Commons Public Domain Dedication waiver (http://creativecommons.org/publicdomain/zero/1.0/) applies to the data made available in this article, unless otherwise stated in a credit line to the data. 
decreased ruminal fluid $\mathrm{pH}$, which leads to subacute ruminal acidosis (SARA) [8]. In the process, endotoxin, also called lipopolysaccharide (LPS), is released as a result of the massive proliferation and breakdown of bacteria, and then triggers the release of histamine [9]. The accumulation of histamine delays the regeneration of epithelial cells, increases the permeability of rumen wall, which allows the metabolites such as endotoxin to enter the peripheral blood circulation [10]. Endotoxins activate the inflammatory response in claw lamellar tissue, increase the permeability of the capillary wall, lead to the microcirculation disorder of the claw, and ultimately contribute to the appearance of laminitis [11].

At present, there is still no effective method for the prevention and treatment of laminitis. Studies have shown that rumen modifiers like monensin can alleviate the severity of laminitis [7, 12]. However, there are growing concerns about food safety and drug resistance. On the other hand, medicinal plants, due to their low drug resistance and multi-target therapeutic properties, have become a potential source for feed supplements or alternative drugs for various diseases [13].

Angelica sinensis, the dried root of Angelica sinensis, is a traditional Chinese herbal medicine that has long been used for nourishing, replenishing blood and relieving pain [14]. It has shown that the extracts of Angelica sinensis have certain therapeutic effect on blood deficiency model and anemia model in mice $[15,16]$. Modern pharmacological studies have demonstrated that Angelica sinensis and its extracts possess multiple beneficial properties such as anti-inflammation, antioxidation, antitumor, neuroprotection [17-19]. Angelica polysaccharide (AP), a $\beta$-d-pyranoid polysaccharide, is the major bioactive component of Angelica sinensis [20]. Accumulating pieces of evidence have confirmed the anti- inflammatory effect of AP. For example, AP mitigated the inflammatory injury induced by LPS in PC-12 cell line [21] and neuronal cell line HT22 [22]. Hence, we hypothesized that AP might have some protective effects on bovine laminitis, but the related literature is limited.

The aim of this study was to investigate the potential protective effects of AP on LPS-induced inflammatory claw dermal cells in vitro, and provide theoretical basis for the application of AP on bovine laminitis in the future.

\section{Results \\ Cytotoxicity of AP on claw dermal cells}

As shown in Fig. 1, the indicated concentrations of AP treated for 24 or $48 \mathrm{~h}$ had no cytotoxic effects on claw dermal cells. Thus, $1,5,10,50,100 \mu \mathrm{g} / \mathrm{mL}$ AP could be used for further research.

\section{Effects of AP on the levels of inflammatory mediators} LPS induced an increase in the levels of TNF- $\alpha$, IL-1 $\beta$, IL-6, NO compared with the control group $(P<0.01)$ (Fig. 2).

Administration of $1 \mu \mathrm{g} / \mathrm{mL}$ AP had no difference in TNF- $\alpha$ and IL- 6 levels compared with those in the LPStreated group for $24 \mathrm{~h}(P>0.05)$, but could significantly reduce the levels of TNF- $\alpha$ and IL- 6 at $48 \mathrm{~h}$. The other doses of AP significantly reduced the levels of TNF- $\alpha$ and IL-6 for the indicated times $(P<0.01)$ (Fig. 2 A,C).

With $1,5 \mu \mathrm{g} / \mathrm{mL}$ AP treatment for $24 \mathrm{~h}$, there was no significant difference of IL-1 $\beta$ level compared with that in the LPS-treated group $(P>0.05)$, while $10,50,100 \mu \mathrm{g} /$ $\mathrm{mL}$ AP significantly reduced the IL- $1 \beta$ level $(P<0.01)$. The indicated doses of AP obviously reduced the IL-1 $\beta$ level at $48 \mathrm{~h}$ (Fig. 2B).

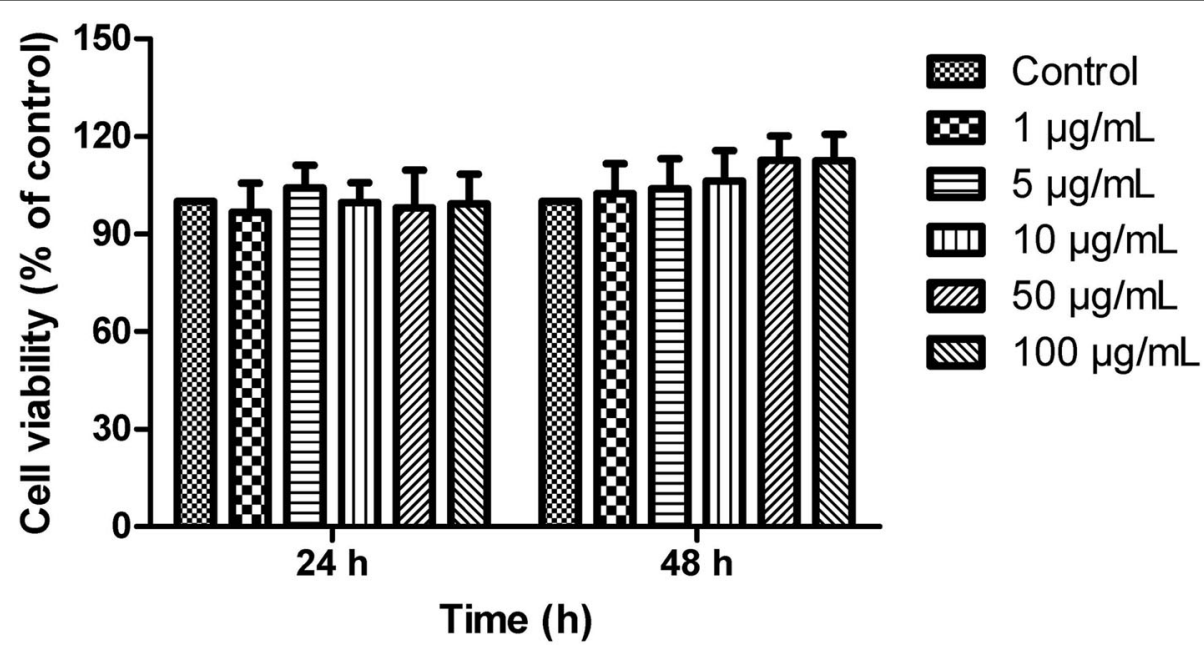

Fig. 1 Cytotoxic of angelica polysaccharide (AP) on claw dermal cells. Cell viability was measured by cell counting kit-8 (CCK-8) method with the treatment of various concentrations $(1,5,10,50,100 \mu \mathrm{g} / \mathrm{mL})$ of AP for 24 or $48 \mathrm{~h}$. The data were presented as mean \pm standard deviations $(n=6)$ 

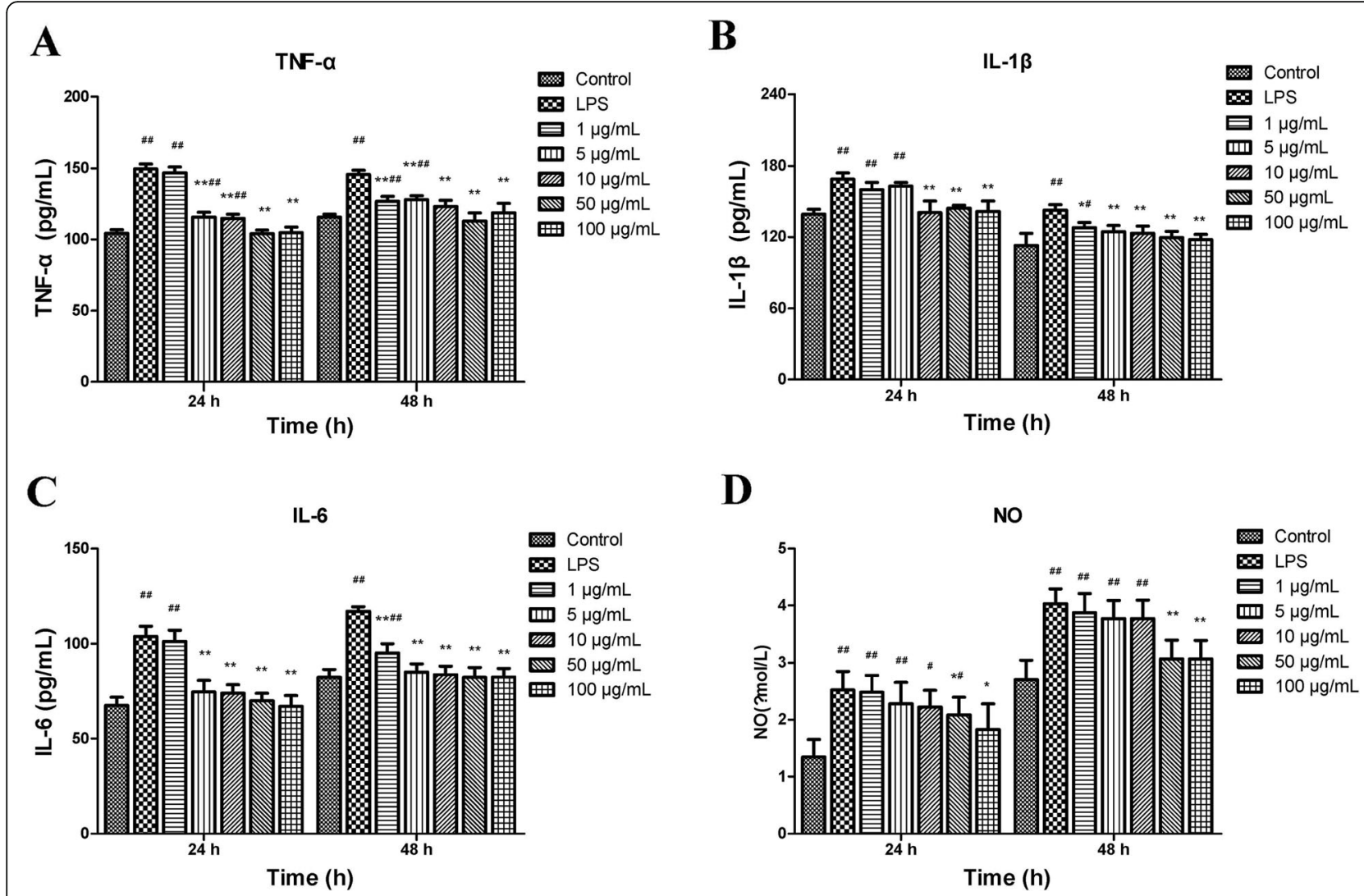

Fig. 2 Effects of angelica polysaccharide (AP) on the levels of tumor necrosis factor-a (TNF-a) (A), interleukin-1 $\beta$ (IL-1 $\beta)(B)$, interleukin-6 (IL-6) (C), nitric oxide (NO) (D) in LPS-induced claw dermal cells. Cells were exposed to various concentrations of AP $(1,5,10,50,100 \mu \mathrm{g} / \mathrm{mL}) \mathrm{with}$ or without the presence of $10 \mu \mathrm{g} / \mathrm{mL}$ LPS for 24 and $48 \mathrm{~h}$. The data were presented as mean \pm standard deviations $(n=6)$. ${ }^{*} P<0.05$ vs. LPS model group; ${ }^{* *} P<0.01$ vs. LPS model group. ${ }^{\#} P<0.05$ vs. control group; ${ }^{\# \#} P<0.01$ vs. control group

Treatment with $50,100 \mu \mathrm{g} / \mathrm{mL}$ AP reduced the NO level at $24 \mathrm{~h}(P<0.05)$ and at $48 \mathrm{~h}(P<0.01)$, while no significant difference was found in $\mathrm{NO}$ compared to LPS-treated group $(P>0.05)$ using other doses (Fig. 2D).

Based on the above results, 10, 50, $100 \mu \mathrm{g} / \mathrm{mL}$ AP performed better anti-inflammatory effects. Therefore, the concentrations of $10,50,100 \mu \mathrm{g} / \mathrm{mL}$ AP were used for further research.

\section{Effects of AP on relative mRNA levels of chemokines}

As shown in Fig. 3, the gene expression levels of CCL2, CCL20, CXCL2, CXCL8, CXCL10 were upregulated significantly in response to LPS challenge. AP treatment downregulated significantly the gene expression levels of these chemokines compared with those in LPS-treated group $(P<0.01)$ in a dose dependent manner.

\section{Effects of AP on relative mRNA levels of TLR4 and MyD88} As shown in Fig. 4, LPS upregulated markedly the mRNA levels of TLR4 and MyD88 compared with those in the control group $(P<0.01)$. All dosages of AP treatment suppressed significantly these gene expression levels at the indicated times $(P<0.01)$.

\section{Effects of AP on protein expression of NF-KB and MAPKs pathways}

It was shown in Fig. 5 that LPS increased significantly the protein levels of p-p65, p-IкB $\alpha, p$-ERK, p-JNK, p-p38 compared with the control group $(P<0.01)$. In comparison with the LPS-treated group, 10, 50, $100 \mu \mathrm{g} / \mathrm{mL} \mathrm{AP}$ treated for $48 \mathrm{~h}$ reduced the protein levels of $\mathrm{p}$-p65, $\mathrm{p}$ IкB $\alpha, \mathrm{p}$-ERK, $\mathrm{p}-\mathrm{JNK}, \mathrm{p}-\mathrm{p} 38$ significantly $(P<0.01)$.

\section{Discussion}

Laminitis, an inflammation of the claw laminae, is one of the most significant diseases in dairy industry, accounting for $41 \%$ cases of bovine lameness [3]. The laminitisrelated diseases not only lead to low milk production, but also relate to weight loss and reproductive capacity reduction, resulting in hidden costs of dairy farming [23].

Lipopolysaccharide (LPS), also known as endotoxins, plays a crucial role in the pathologies of laminitis. 


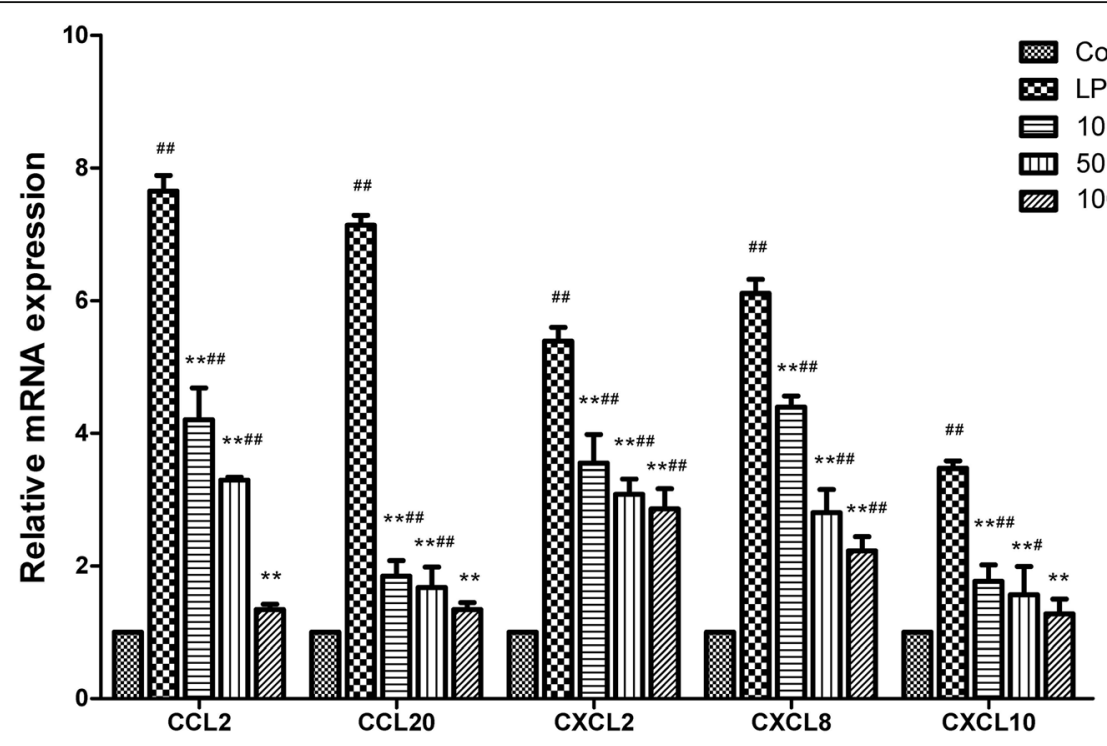

Fig. 3 Effects of angelica polysaccharide (AP) on mRNA expression levels of chemokines (CCL2, CCL20, CXCL2, CXCL8, CXCL10) in LPS-induced claw dermal cells. Cells were exposed to various concentrations of AP $(10,50,100 \mu \mathrm{g} / \mathrm{mL})$ with or without the presence of $10 \mu \mathrm{g} / \mathrm{mL} \mathrm{LPS}$ for 48 h. The data were presented as mean \pm standard deviations $(n=6)$. ${ }^{*} P<0.05$ vs. LPS model group; ${ }^{* *} P<0.01$ vs. LPS model group. ${ }^{\#} P<0.05$ vs. control group: $\#$ $P<0.01$ vs. control group

Elevated LPS concentrations in plasma were detected in both subclinical and chronic laminitis dairy cows [24], as well as in the high-grain diet model of goats [25]. Lipopolysaccharide transported to the peripheral blood could activate the inflammatory response in the lamellar tissue and result in laminar damage [26]. Additionally, LPS with higher concentrations had negative effects on the tissue integrity of hoof explants in vitro [27]. In our previous study, an inflammatory model on claw dermal cells with $10 \mu \mathrm{g} / \mathrm{mL}$ LPS had established [28]. Therefore, in this study, LPS was used as a stimulus to establish an inflammatory model of claw dermal cells to explore the possible therapeutic drug for laminitis in vitro.

The anti-inflammatory effects of AP had been verified in previous studies $[29,30]$, but the effects on claw dermal cells remain unclear. It is widely accepted that the excessive production of some inflammatory mediators and chemokines are tightly related to the inflammatory injury [31]. TNF- $\alpha$, IL-1 $\beta$ and IL-6 are typical proinflammatory cytokines that play a pivotal role in the

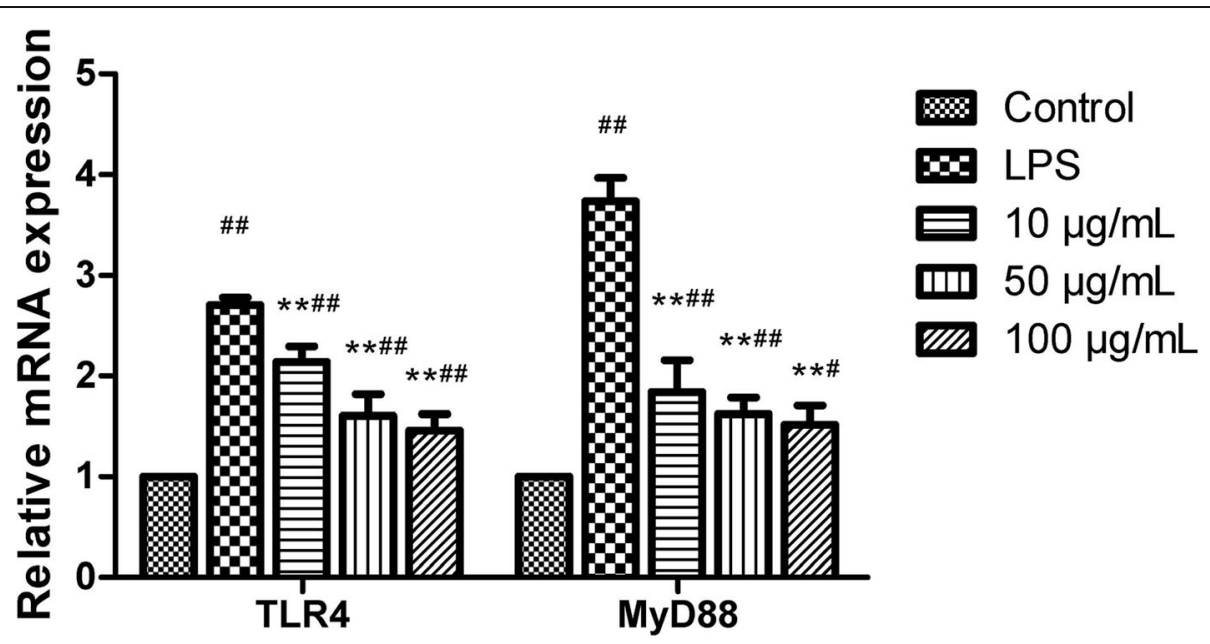

Fig. 4 Effects of angelica polysaccharide (AP) on mRNA expression levels of toll-like receptor 4 (TLR4) and myeloid differentiation factor 88 (MyD88) in LPS-induced claw dermal cells. Cells were exposed to various concentrations of AP $(10,50,100 \mu \mathrm{g} / \mathrm{mL})$ with or without the presence of $10 \mu \mathrm{g} / \mathrm{mL}$ LPS for $48 \mathrm{~h}$. The data were presented as mean \pm standard deviations $(n=6) .{ }^{*} P<0.05 \mathrm{vs}$. LPS model group; ${ }^{* *} P<0.01$ vs. LPS model group. $P<0.05$ vs. control group. ${ }^{\# \#} P<0.01$ vs. control group 

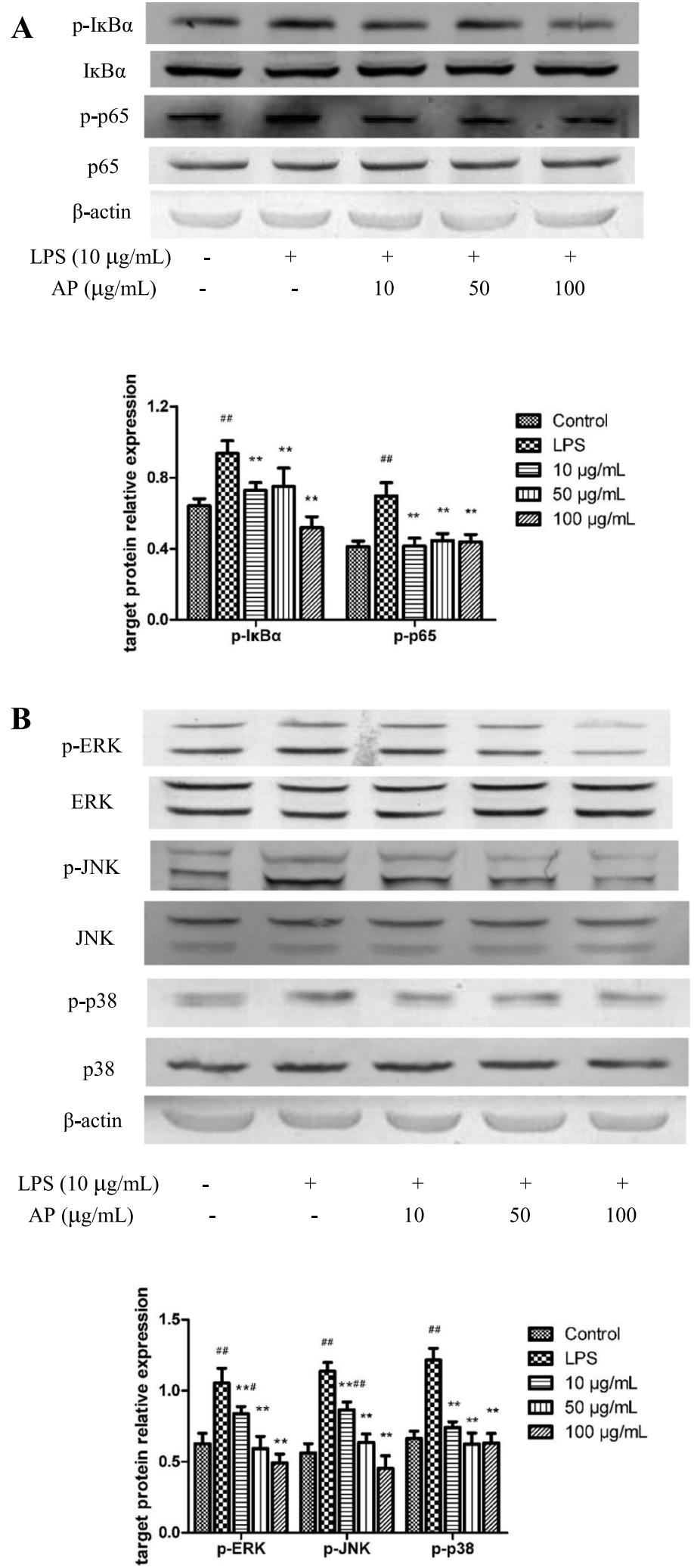

Fig. 5 (See legend on next page.) 
(See figure on previous page.)

Fig. 5 Effects of angelica polysaccharide (AP) on protein expression of nuclear factor-KB (NF-KB) (A) and mitogen-activated protein kinase (MAPK) (B) signaling pathways in LPS-induced claw dermal cells. Cells were exposed to various concentrations of AP $(10,50,100 \mu \mathrm{g} / \mathrm{mL})$ with or without the presence of $10 \mu \mathrm{g} / \mathrm{mL}$ LPS for $48 \mathrm{~h}$. The data were presented as mean \pm standard deviations $(n=6) .{ }^{*} P<0.05$ vs. LPS model group; ${ }^{* *} P<0.01$ vs. LPS model group. ${ }^{\#} P<0.05$ vs. control group; ${ }^{\# \#} P<0.01$ vs. control group

pathogenesis of inflammatory response [32]. Previous studies have reported that the IL-1 $\beta$ and IL-6 expression in laminar was implicated in the degree of lamellar injury [33]. The higher levels of TNF- $\alpha$ and IL- 6 in plasma were also detected in laminitis cows [24]. In addition, the secretion of these cytokines can affect the synthesis of mediators such as PG, leukotriene, and NO [34]. As an intracellular messenger molecule, $\mathrm{NO}$ regulates the various functions of cells and involves in the defense functions of the immune system [35]. Excessive secretion of NO leads to cytotoxicity and mediates the inflammation progress [36]. Chemokines, or chemotactic cytokines, are small heparin-binding proteins that direct the migration and positioning of immune cells, and play a crucial role in the inflammation injury and innate immune system [37, 38]. The CCL2, CCL20, CXCL2, CXCL8, and CXCL10 measured in this experiment are common pro-inflammatory chemokines from the CCL and CXCL subfamily of chemokines, which actively participate in the inflammatory response under some proinflammatory stimuli like LPS, IL-1, TNF- $\alpha$ [39]. Together, these pro-inflammatory substances could exhibit cytotoxic effects and accelerate the inflammatory response [40]. The reduction of these inflammatory indicators could serve as a therapy signal for inflammation amelioration.

Our results showed that AP markedly reduced the production of TNF- $\alpha$, IL- $1 \beta$, IL- 6 , and NO, and downregulated the mRNA expression of CCL2, CCL20, CXCL2, CXCL8, CXCL10, indicating that AP alleviated the LPS-induced inflammatory response in claw dermal cells by inhibiting the production of inflammatory mediators and chemokines.

It is widely known that toll-like receptor 4 (TLR4) is the main receptor for LPS stimulation [41]. Once recognized, the LPS complex is capable of initiating a series of cascades via the stimulation of myeloid differentiation factor 88 (MyD88), including the initiation of NF- $\mathrm{kB}$ and MAPK signaling pathways, and ultimately induces inflammatory cytokine and chemokine expression [42].

Nuclear factor- $-\mathrm{B}(\mathrm{NF}-\mathrm{kB})$ is a transcription factor, which involves in the regulation of multiple cell functions, such as proliferation, apoptosis and inflammation, and plays a crucial role in the regulation of proinflammatory genes [43]. The predominant form of NF$\kappa \mathrm{B}$ is heterodimer $\mathrm{p} 50-\mathrm{p} 65$ [44]. In an unstimulated state, NF- $k B$ is located in cytoplasm under a silent state because of the binding with $\mathrm{\kappa B}$ inhibitor (І $\mathrm{kB}$ ).
Stimulator like LPS could induce the phosphorylation and degradation of ІкB $\alpha$, followed by NF-кB/ІкB complex dissociation, as well as the NF- $\kappa B$ phosphorylation. Then, the phosphorylated NF- $\mathrm{BB}$ translocated into the nucleus and induced the expression of pro-inflammatory mediators [45].

Mitogen-activated protein kinases (MAPKs) are a family of serine/ threonine protein kinases, consisting of extracellular signal-regulated kinase 1/2 (ERK1/2), p38, and c-Jun NH2-terminal kinase (JNK) [46]. The MAPK signaling pathway plays an important role in the early stage inflammatory responses and the activation of NF$\kappa B$ pathway [47]. Previous studies have demonstrated that AP exerted its anti-inflammatory effect through repression of NF-kB and MAPK pathways [22, 48]. Our data showed that AP restrained the initiation of NF- $\mathrm{KB}$ and MAPK pathways on claw dermal cells by decreasing the phosphorylation of IKB $\alpha$, p 65 and ERK, JNK, p38, which is consistent with the previous studies.

\section{Conclusions}

In conclusion, the present study demonstrated that AP protects the primary claw dermal cells of dairy cow against LPS-induced inflammatory injury by decreasing the pro-inflammatory mediators and chemokines, which may be regulated by NF- $\mathrm{KB}$ and MAPK signaling pathways. Altogether, AP might serve as a suitable therapeutic candidate for the management of bovine laminitis, the biological significance of these results needs to be investigated further in the larger in vivo field trials.

\section{Methods \\ Materials}

Dulbecco's Modified Eagle Medium (DMEM), fetal bovine serum (FBS) and $1 \times$ Insulin-Transferrin-Selenium (ITS) were obtained from Gibco (Grand Island, NY). LPS (Escherichia coli O55: B5) was purchased from Sigma (St. Louis, USA). Angelica polysaccharide ( $\geq 90 \%$ purity), cell counting kit-8 (CCK-8), RIPA cell lysis buffer, BCA protein assay kit, and NBT/BCIP chromogen kit were acquired from Solarbio (Beijing, China). ELISA kits of tumor necrosis factor- $\alpha$ (TNF- $\alpha$ ) (DG90837Q), interleukin (IL)-1 $\beta$ (DG90995Q) and IL-6 (DG90838Q) for dairy cow were purchased from DG Biotech Co. Ltd. (Beijing, China). Nitric oxide (NO) kit (A013-2-1) was purchased from Nanjing Jiancheng Bioengineering Institute (Nanjing, China). The primary antibodies against 
phosphor-JNK, phosphor-ERK, phosphor-p38, JNK, ERK, and p38 were obtained from Cell Signaling Technology (Danvers, MA, USA). Antibodies for phosphorI $\mathrm{B} \alpha$, phosphor-p65 NF-кB, ІкB $\alpha$, p65 NF- $\mathrm{kB}$ and $\beta-$ actin were obtained from Bioss (Woburn, MA, USA). The HRP-conjugated secondary antibody was purchased from ZSGB-Bio (Beijing, China). Ultrapure RNA extraction kit and HiFiscript cDNA Synthesis Kit were purchased from CWBIO (Beijing, China). $2 \times$ Fast Super EvaGreen $^{\circ}$ qPCR Mastermix was acquired from US Everbright Inc.(CA, USA). All reagents used in this study were pyrogen-free (Horseshoe Crab Reagent Manufactory, Xiamen, China). All other chemicals were of reagent grade.

\section{Cell culture and treatment}

Claw dermal cells of dairy cow were isolated using the tissue adherent culture method as previously described [28]. Claw lamellar tissues were collected at a local abattoir from adult healthy dairy cows. The tissues were aseptically cut off and put into sterile saline solution with antibiotics (200 units/mL of Penicillin, $200 \mu \mathrm{g} / \mathrm{mL}$ of Streptomycin), and then transported on ice to the laboratory within $2 \mathrm{~h}$. The acquired tissues were washed with sterile phosphate buffered saline (PBS) for 3 times, trimmed into small pieces and soaked in $0.25 \%$ trypsin solution at $4^{\circ} \mathrm{C}$ for $18-24 \mathrm{~h}$. After rinsing with PBS, the epidermis and dermis were separated. The dermis pieces were seeded onto 6-well plates coated with rat tail collagen, cultured in DMEM, supplemented with $15 \%$ FBS, $1 \times$ ITS, 0.025 M HEPES, 200 units $/ \mathrm{mL}$ of Penicillin, $200 \mu \mathrm{g} / \mathrm{mL}$ of Streptomycin, and maintained in $5 \% \mathrm{CO}_{2}$ incubator at $37^{\circ} \mathrm{C}$. Medium was replaced every $2-3$ days. Tissue pieces were removed when cells were about $50 \%$ confluence. Upon 80-90\% confluence, cells were detached with $0.25 \%$ trypsin-EDTA solution and seeded into $25 \mathrm{~cm}^{2}$ flasks.

The claw dermal cells were exposed to different concentrations of $\operatorname{AP}(1,5,10,50,100 \mu \mathrm{g} / \mathrm{mL})$ with or without the stimulation of $10 \mu \mathrm{g} / \mathrm{mL}$ LPS for different times based on different experimental conditions.

\section{Cell viability assay}

Cell viability was measured using the Cell Counting Kit8 (CCK-8). Claw dermal cells were seeded into 96-well plates at a density of $1 \times 10^{5}$ cells/ well and cultured until $80-90 \%$ confluency. The cells were treated with different concentrations of AP $(1-100 \mu \mathrm{g} / \mathrm{mL})$ for 24 and $48 \mathrm{~h}$. Then $10 \mu \mathrm{L}$ CCK- 8 was added into each well. The cells were incubated at $37^{\circ} \mathrm{C}$ for $1 \mathrm{~h}$. The absorbance at $450 \mathrm{~nm}$ was measured by a microplate reader (Bio-Rad, CA, USA).

\section{Cytokine measurement}

The levels of TNF- $\alpha$, IL- $1 \beta$ and IL- 6 in supernatants of claw dermal cells were detected using commercial ELISA kits, according to the manufacturer's guidelines. The OD value at a wavelength of $450 \mathrm{~nm}$ was measured by a microplate reader (Bio-Rad, CA, USA). The NO concentration in dermal cell supernatant was measured using Griess colorimetric method, following the manufacturer's protocol. Absorbance was measured at $550 \mathrm{~nm}$ by a microplate reader (Bio-Rad, CA, USA). Draw a standard curve with the standard solution concentrations as the horizontal axis and the measured OD value as the vertical axis, then calculate the concentrations of cytokines on the basis of standard curve. The intra- and inter- CV (coefficients of variations) were less than $15 \%$.

\section{Quantitative real-time PCR analysis}

Total RNA was extracted from dermal cells using Ultrapure RNA extraction kit following the manufacturer's protocol. The concentration and purity (OD260/OD280 absorption ratio $>1.8$ ) of total RNA were evaluated by a NanoDrop 2000 spectrophotometer (Thermo Scientific, Ottawa, ON, Canada). Subsequently, the total RNA was reverse transcribed into cDNA with the use of HiFiscript cDNA Synthesis Kit according to the manufacturer's instructions. Quantitative real-time PCR was performed using $2 \times$ Fast Super EvaGreen ${ }^{\circ}$ qPCR Mastermix on a LightCycler96 Real-Time PCR system (Roche, Basel, Switzerland). Primer sequences are listed in Table 1. The following cycling conditions were performed: $95{ }^{\circ} \mathrm{C}$ for $300 \mathrm{~s}, 40$ cycles of $95{ }^{\circ} \mathrm{C}$ for $5 \mathrm{~s}, 56{ }^{\circ} \mathrm{C}$ for $30 \mathrm{~s}$ and $72{ }^{\circ} \mathrm{C}$ for $15 \mathrm{~s}$. Negative control sample with water was set in the reaction mixture instead of cDNA templates. The relative expression of target genes was normalized relative to the level of the control (GAPDH) and calculated using the $2^{-\Delta \Delta C t}$ method [49].

\section{Western blot analysis}

Total proteins from claw dermal cells were extracted with RIPA cell lysis buffer and quantified by BCA protein assay kit. Total protein $(20-50 \mu \mathrm{g} /$ sample) was separated on $12 \%$ SDS-polyacrylamide gel and transferred to nitrocellulose membranes. Nonspecific binding sites of membranes were blocked with $5 \%$ non-fat milk for $1 \mathrm{~h}$ at room temperature. Membranes were incubated with antibodies specific for JNK, phosphor-JNK, ERK, phosphor-ERK, p38, phosphor-p38, ІкB $\alpha$, phosphorI $\kappa B \alpha$, p 65 NF- $\kappa B$, phosphor-p65 NF- $\mathrm{KB}$ and $\beta$-actin at $4{ }^{\circ} \mathrm{C}$ overnight, and then incubated with HRPconjugated secondary antibodies at room temperature for $1 \mathrm{~h}$. Immunoblot signals were visualized with NBT/ BCIP chromogen kit. Densitometric values were obtained from 3 separate experiments using ImageJ software (NIH, Bethesda, MD). 
Table 1 Primer sequences used for amplification of qPCR

\begin{tabular}{llllc}
\hline Accession $\mathbf{N o}$. & Genes $^{\mathbf{a}}$ & Sense & Antisense & Product size(bp) \\
\hline NM_174198.6 & TLR4 & AGCTTCAACCGTATCATGGCCTCT & ACTAAGCACTGGCATGTCCTCCAT & 166 \\
NM_001014382.2 & MyD88 & AAGTACAAGCCAATGAAGAAAGAG & GAGGCGAGTCCAGAACCAG & 102 \\
NM_174006.2 & CCL2 & CGCTCAGCCAGATGCAATTA & GACCCATTCTGCTTGGGGT & 184 \\
NM_174263.2 & CCL20 & TTGATGTCAGTGCTATTGCT & ACCCACTTCTTCTTGGATC & 209 \\
NM_174299.3 & CXCL2 & ACCGAAGTCATAGCCACTCTC & TCCAGATGGCCTTAGGAGGT & 218 \\
NM_173925.2 & CXCL8 & AAACACATTCCACACCTTC & TCTTCACAAATACCTGCACA & 171 \\
NM_001046551 & CXCL10 & CTCGAACACGGAAAGAGGCA & TCCACGGACAATTAGGGCTT & 117 \\
NM_001034034.2 & GAPDH & CACCCTCAAGATTGTCAGCA & GGTCATAAGTCCCTCCACGA & 103 \\
\hline
\end{tabular}

${ }^{\mathrm{a} T L R 4}$, toll-like receptor 4, MyD88, myeloid differentiation factor 88, GAPDH, Glyceraldehyde 3-phosphate dehydrogenase

\section{Statistical analysis}

Data were presented as mean \pm standard deviations (SD) of at least three independent experiments. The statistical analyses were performed with GraphPad Prism 5 (GraphPad Software, La Jolla, USA). Significant differences were evaluated by one-way analysis of variance (ANOVA) with Duncan's post hoc test using SPSS 21.0 software (SPSS Inc., Chicago, IL). $P<0.05$ was considered as statistically significant.

\section{Abbreviations \\ AP: Angelica polysaccharide; CCK-8: Cell counting kit-8; DMEM: Dulbecco's Modified Eagle Medium; ELISA: Enzyme-linked immunosorbent assay; FBS: Fetal bovine serum; IkBa: KB inhibitor a; IL-1 $\beta$ : Interleukin-1 $\beta$; ITS: Insulin- Transferrin-Selenium; LPS: Lipopolysaccharides; MAPK: Mitogen-activated protein kinases; MyD88: Myeloid differentiation factor 88; NF-kB: Nuclear factor-KB; NO: Nitric oxide; PBS: Phosphate buffered saline; TNF-a: Tumor necrosis factor-a; TLR4: Toll-like receptor 4}

\section{Supplementary Information}

The online version contains supplementary material available at https://doi. org/10.1186/s12917-021-02952-4.

Additional file 1. The original, full length blots of western blot.

\section{Acknowledgements}

Not applicable.

\section{Authors' contributions}

YZM conceived and designed the study, and critically revised the manuscript. MYT performed most of the experiments, analyzed the results, and drafted the manuscript. KL and RNL assisted in experimental design, data interpretation and manuscript preparation. JLD and DMZ assisted in ELISA, qPCR and WB experiments. All authors read and approved the final manuscript.

\section{Funding}

This research was supported by Hebei key research and development program (19226611D), In novation ability training program of Hebei Province for Graduate candidate (CXZZBS2020101), Project of Bureau of Hebei Animal Husbandry and Veterinary Medicine (2013107), Hebei Dairy Cattle Innovation Team of Modern Agro-industry Technology Research System (HBCT2018120406), and Hebei Beef Innovation Team of Modern Agroindustry Technology Research System (HBCT20181130405). The funding body had no role in the design of the study, collection, analysis, and interpretation of data or in the writing of this manuscript.

\section{Availability of data and materials}

The datasets used and/or analysed during the current study are available from the corresponding author on reasonable request. The original sequences we used for primer sequences design can be found in GenBank under the accession numbers: NM_174198.6, NM_001014382.2, NM_174006.2, NM_174263.2, NM_174299.3, NM_173925.2, NM_001046551, NM_001034034.2.

\section{Declarations}

\section{Ethics approval and consent to participate}

Claw lamellar tissues were collected at a local abattoir from healthy adult dairy cows at Baoding Lianchi slaughter house (Hebei, China) and used with the consent of the slaughter house. All dairy cows were slaughtered for meat production and no animal was slaughtered specifically for the purpose of tissue collection.

\section{Consent for publication}

Not applicable.

\section{Competing interests}

The authors declare that they have no competing interests.

\section{Author details}

${ }^{1}$ College of Veterinary Medicine, Hebei Agricultural University, 2596 Lekai South Street, Hebei 071001 Baoding, China. ${ }^{2}$ International Joint Research Laboratory for Fish Immunopharmacology, Freshwater Fisheries Research Center, Chinese Academy of Fishery Sciences, 214081 Wuxi, Jiangsu, China.

${ }^{3}$ College of Veterinary Medicine, Shanxi Agricultural University, Shanxi 030801 Taigu, China.

Received: 15 December 2020 Accepted: 28 June 2021

Published online: 19 July 2021

\section{References}

1. Dolecheck K, Bewley J. Animal board invited review: Dairy cow lameness expenditures, losses and total cost. Animal. 2018;12:1462-74.

2. Huxley JN. Impact of lameness and claw lesions in cows on health and production. Livest Sci. 2013;156:64-70.

3. Boosman R, Nemeth F, Gruys E. Bovine laminitis: clinical aspects, pathology and pathogenesis with reference to acute equine laminitis. Vet Q. 1991;13: 163-71

4. Seesupa S, Kanistanon K, Pilachai R, Aiumlamai S. Prevalence of Subclinical Laminitis and Its Effects on Reproductive Performance in Lactating Cows in Thailand. Thai J Vet Med. 2016:46:109-17.

5. Alvergnas M, Strabel T, Rzewuska K, Sell-Kubiak E. Claw disorders in dairy cattle: Effects on production, welfare and farm economics with possible prevention methods. Livest Sci. 2019;222:54-64.

6. Greenough. Bovine laminitis and lameness: a hands-on approach. Elsevier Health Sciences; 2007.

7. Langova L, Novotna I, Nemcova P, Machacek M, Havlicek Z, Zemanova M, Chrast V. Impact of Nutrients on the Hoof Health in Cattle. Animals (Basel). 2020;10:1824. 
8. Gozho GN, Plaizier JC, Krause DO, Kennedy AD, Wittenberg KM. Subacute ruminal acidosis induces ruminal lipopolysaccharide endotoxin release and triggers an inflammatory response. J Dairy Sci. 2005;88:1399-403.

9. Tavares NC, Barbosa AA, Bermudes RF, Rechsteiner SMEF, Cruz LAX, Bruhn FRP, Silva PM, Martins CF. Impact of high-energy diets on the rumen environment and digital cushion in confined cattle. Pesqui Vet Brasil. 2019; 39:970-7.

10. Aschenbach JR, Furll B, Gabel G. Histamine affects growth of sheep ruminal epithelial cells kept in primary culture. Zentralbl Veterinarmed A. 1998;45: 411-6.

11. Ding J, Li S, Jiang L, Li Y, Zhang X, Song Q, Hayat MA, Zhang JT, Wang H. Laminar Inflammation Responses in the Oligofructose Overload Induced Model of Bovine Laminitis. Front Vet Sci. 2020;7:351.

12. Westwood CT, Bramley E, Lean IJ. Review of the relationship between nutrition and lameness in pasture-fed dairy cattle. N Z Vet J. 2003;51:208-18.

13. Ayrle $H$, Mevissen $M$, Kaske M, Nathues $H$, Gruetzner N, Melzig M, Walkenhorst M. Medicinal plants - prophylactic and therapeutic options for gastrointestinal and respiratory diseases in calves and piglets? A systematic review. BMC Vet Res. 2016;12:1-31.

14. Wei W, Zeng R, Gu C, Qu Y, Huang L. Angelica sinensis in China-A review of botanical profile, ethnopharmacology, phytochemistry and chemical analysis. J Ethnopharmacol. 2016.

15. Li PL, Sun HG, Hua YL, Ji P, Zhang L, Li JX, Wei YM. Metabolomics study of hematopoietic function of Angelica sinensis on blood deficiency mice model. J Ethnopharmacol. 2015;166:261-9.

16. Liu PJ, Hsieh WT, Huang SH, Liao HF, Chiang BH. Hematopoietic effect of water-soluble polysaccharides from Angelica sinensis on mice with acute blood loss. Exp Hematol. 2010;38:437-45.

17. Kim YJ, Lee JY, Kim HJ, Kim DH, Lee TH, Kang MS, Park W. Anti-Inflammatory Effects of Angelica sinensis (Oliv.) Diels Water Extract on RAW 264.7 Induced with Lipopolysaccharide. Nutrients. 2018;10:647.

18. Wei WL, Zeng R, Gu CM, Qu Y, Huang LF. Angelica sinensis in China-A review of botanical profile, ethnopharmacology, phytochemistry and chemical analysis. J Ethnopharmacol. 2016;190:116-41.

19. Huang SH, Lin CM, Chiang BH. Protective effects of Angelica sinensis extract on amyloid beta-peptide-induced neurotoxicity. Phytomedicine. 2008;15: 710-21

20. Wang J, Ge B, Li Z, Guan F, Li F. Structural analysis and immunoregulation activity comparison of five polysaccharides from Angelica sinensis. Carbohydr Polym. 2016;140:6-12.

21. Li R, Yin F, Guo Y, Ruan Q, Zhu Q. Angelica polysaccharide protects PC-12 cells from lipopolysaccharide-induced injury via down-regulating microRNA223. Biomed Pharmacother. 2018;108:1320-7.

22. Zhou Y, Guo X, Chen W, Liu J. Angelica polysaccharide mitigates lipopolysaccharide-evoked inflammatory injury by regulating microRNA-10a in neuronal cell line HT22. Artif Cells Nanomed Biotechnol. 2019;47:3194201.

23. Kenneth V, Nordlund, Nigel B, Cook, Garrett R. Oetzel. Investigation Strategies for Laminitis Problem Herds. J Dairy Sci. 2004;87:E27-35.

24. Zhang X, Ding J, Li Y, Song Q, Li S, Hayat MA, Zhang J, Wang H. The changes of inflammatory mediators and vasoactive substances in dairy cows' plasma with pasture-associated laminitis. BMC Vet Res. 2020;16:1-10.

25. Zhang RY, Jin W, Feng PF, Liu JH, Mao SY. High-grain diet feeding altered the composition and functions of the rumen bacterial community and caused the damage to the laminar tissues of goats. Animal. 2018;12:251120.

26. Andersen $\mathrm{PH}$. Bovine endotoxicosis - Some aspects of relevance to production diseases. A review. Acta Vet Scand. 2003:44:1-15.

27. Reisinger N, Schaumberger S, Nagl V, Hessenberger S, Schatzmayr G. Concentration Dependent Influence of Lipopolysaccharides on Separation of Hoof Explants and Supernatant Lactic Acid Concentration in an Ex Vivo/ In Vitro Laminitis Model. PLoS One. 2015;10:e0143754.

28. Tian MY, Fan JH, Zhuang ZW, Dai F, Wang CY, Hou HT, Ma YZ. Effects of silymarin on p65 NF-kappaB, p38 MAPK and CYP450 in LPS-induced hoof dermal inflammatory cells of dairy cows. BMC Vet Res. 2019;15:127.

29. Dai X, Hackmann TJ, Lobo RR, Faciola AP. Lipopolysaccharide Stimulates the Growth of Bacteria That Contribute to Ruminal Acidosis. Appl Environ Microbiol. 2020;86:e02193-19.

30. Li MM, Zhang Y, Wu J, Wang KP. Polysaccharide from Angelica Sinensis Suppresses Inflammation and Reverses Anemia in Complete Freund's Adjuvant-induced Rats. Curr Med Sci. 2020;40:265-74.
31. Tang J, Luo K, Li Y, Chen Q, Tang D, Wang D, Xiao J. Capsaicin attenuates LPS-induced inflammatory cytokine production by upregulation of LXRalpha. Int Immunopharmacol. 2015;28:264-9.

32. Wang J, Wang H, Zhang H, Liu Z, Ma C, Kang W. Immunomodulation of ADPs-1a and ADPs-3a on RAW264.7 cells through NF-kappaB/MAPK signaling pathway. Int J Biol Macromol. 2019;132:1024-30.

33. Dern K, Watts M, Werle B, van Eps A, Pollitt C, Belknap J. Effect of Delayed Digital Hypothermia on Lamellar Inflammatory Signaling in the Oligofructose Laminitis Model. J Vet Intern Med. 2017;31:575-81.

34. Hanada T, Yoshimura A. Regulation of cytokine signaling and inflammation. Cytokine Growth F R. 2002;13:413-21.

35. Mason RP, Cockcroft JR. Targeting nitric oxide with drug therapy. J Clin Hypertens (Greenwich). 2006;8:40-52.

36. Chen T, Mou Y, Tan J, Wei L, Qiao Y, Wei T, Xiang P, Peng S, Zhang Y, Huang $Z$, et al. The protective effect of CDDO-Me on lipopolysaccharideinduced acute lung injury in mice. Int Immunopharmacol. 2015;25:55-64.

37. Hughes CE, Nibbs RJB. A guide to chemokines and their receptors. Febs J. 2018;285:2944-71

38. Sokol CL, Luster AD. The chemokine system in innate immunity. Cold Spring Harb Perspect Biol. 2015;7:a016303.

39. Charo IF, Ransohoff RM. Mechanisms of disease - The many roles of chemokines and chemokine receptors in inflammation. N Engl J Med. 2006; 354:610-21

40. Rivest S. Molecular insights on the cerebral innate immune system. Brain Behavior Immunity. 2003;17:13-9.

41. Ju Z, Su M, Hong J, Kim E, Jung JH. Anti-inflammatory effects of an optimized PPAR-gamma agonist via NF-kappaB pathway inhibition. Bioorg Chem. 2020;96:103611.

42. Cochet F, Peri F. The Role of Carbohydrates in the Lipopolysaccharide (LPS)/ Toll-Like Receptor 4 (TLR4) Signalling. Int J Mol Sci. 2017;18:2318.

43. Gilmore TD. Introduction to NF-kappaB: players, pathways, perspectives. Oncogene. 2006;25:6680-4

44. Chen J, Stark LA. Crosstalk between NF-kappaB and Nucleoli in the Regulation of Cellular Homeostasis. Cells. 2018;7:157-70.

45. Dong N, Li X, Xue C, Zhang L, Wang C, Xu X, Shan A. Astragalus polysaccharides alleviates LPS-induced inflammation via the NF-kappaB/ MAPK signaling pathway. J Cell Physiol. 2020:235:5525-40.

46. Kim EK, Choi EJ. Pathological roles of MAPK signaling pathways in human diseases. Biochim Biophys Acta. 2010;1802:396-405.

47. Chen L, Deng H, Cui H, Fang J, Zuo Z, Deng J, Li Y, Wang X, Zhao L. Inflammatory responses and inflammation-associated diseases in organs. Oncotarget. 2018;9:7204-18.

48. Gao Z, Zhang C, Tian W, Liu K, Hou R, Yue C, Wu Y, Wang D, Liu J, Hu Y, et al. The antioxidative and hepatoprotective effects comparison of Chinese angelica polysaccharide(CAP)and selenizing CAP (SCAP) in CCl4 induced hepatic injury mice. Int J Biol Macromol. 2017:97:46-54.

49. Livak KJ, Schmittgen TD. Analysis of relative gene expression data using real-time quantitative PCR and the 2(-Delta Delta C(T)) Method. Methods. $2001 ; 25: 402-8$.

\section{Publisher's Note}

Springer Nature remains neutral with regard to jurisdictional claims in published maps and institutional affiliations.

Ready to submit your research? Choose BMC and benefit from:

- fast, convenient online submission

- thorough peer review by experienced researchers in your field

- rapid publication on acceptance

- support for research data, including large and complex data types

- gold Open Access which fosters wider collaboration and increased citations

- maximum visibility for your research: over $100 \mathrm{M}$ website views per year

At $\mathrm{BMC}$, research is always in progress.

Learn more biomedcentral.com/submission 